Article

\title{
Enhanced Thermostability of Glucose Oxidase through Computer-Aided Molecular Design
}

\author{
Xiaoyan Ning ${ }^{1,+}$, Yanli Zhang ${ }^{1,+}$, Tiantian Yuan ${ }^{1}$, Qingbin Li ${ }^{1,2}$, Jian Tian ${ }^{1}$, Weishi Guan ${ }^{1}$, \\ Bo Liu ${ }^{1}$, Wei Zhang ${ }^{1}$, Xinxin $X^{1, *}$ and Yuhong Zhang ${ }^{1, *}$ ii \\ 1 Biotechnology Research Institute, Chinese Academy of Agricultural Sciences, Beijing 100081, China; \\ sjznxy2010@126.com (X.N.); 18770046997@163.com (Ya.Z.); nkyswsnn@163.com (T.Y.); \\ liqingbin2015@sina.com (Q.L.); tianjian@caas.cn (J.T.); GuanWeiShiwork@163.com (W.G.); \\ liubo01@caas.cn (B.L.); zhangwei02@caas.cn (W.Z.) \\ 2 Center for Life Sciences, China Agricultural University, Beijing 100089, China \\ * Correspondence: xuxinxin@caas.cn (X.X.); zhangyuhong@caas.cn (Yu.Z.); \\ Tel./Fax: +86-10-8210-9843 (X.X. \& Yu.Z.) \\ + These authors contributed equally to this work.
}

Received: 5 November 2017; Accepted: 26 January 2018; Published: 31 January 2018

\begin{abstract}
Glucose oxidase (GOD, EC.1.1.3.4) specifically catalyzes the reaction of $\beta$-D-glucose to gluconic acid and hydrogen peroxide in the presence of oxygen, which has become widely used in the food industry, gluconic acid production and the feed industry. However, the poor thermostability of the current commercial GOD is a key limiting factor preventing its widespread application. In the present study, amino acids closely related to the thermostability of glucose oxidase from Penicillium notatum were predicted with a computer-aided molecular simulation analysis, and mutant libraries were established following a saturation mutagenesis strategy. Two mutants with significantly improved thermostabilities, $\mathrm{S} 100 \mathrm{~A}$ and $\mathrm{D} 408 \mathrm{~W}$, were subsequently obtained. Their protein denaturing temperatures were enhanced by about $4.4{ }^{\circ} \mathrm{C}$ and $1.2{ }^{\circ} \mathrm{C}$, respectively, compared with the wild-type enzyme. Treated at $55{ }^{\circ} \mathrm{C}$ for $3 \mathrm{~h}$, the residual activities of the mutants were greater than $72 \%$, while that of the wild-type enzyme was only $20 \%$. The half-lives of S100A and D408W were 5.13- and 4.41-fold greater, respectively, than that of the wild-type enzyme at the same temperature. This work provides novel and efficient approaches for enhancing the thermostability of GOD by reducing the protein free unfolding energy or increasing the interaction of amino acids with the coenzyme.
\end{abstract}

Keywords: glucose oxidase; molecular design; saturation mutagenesis; thermostability

\section{Introduction}

Glucose oxidase (GOD, EC.1.1.3.4) is an aerobic dehydrogenase that catalyses the oxidation of $\beta$-D-glucose into gluconic acid and hydrogen peroxide with molecular oxygen as the electron acceptor. In recent years, GOD has become widely used in the food industry, gluconic acid production and in feed additives, in addition to being used as glucose biosensor for medical and environmental monitoring [1,2]. GOD is the most widely-used analytical reagent coupled with catalase for the detection and estimation of glucose in blood and in industrial solutions [3,4]. In baking processes, hydrogen peroxide produced during the catalytic reaction of GOD can oxidise the mercapto group of gluten into disulphide bonds to improve the mesh structure inside the dough, enhancing its elasticity and the quality of the product [5]. GOD can also be exploited to produce calcium gluconate, zinc gluconate, etc. Compared with traditional metal catalysis and fermentation methods for producing gluconate, enzymatic methods have obvious advantages, such as safety, simple operation, and good product quality [6]. GOD is also used as a new feed additive in the feed industry to improve the intestinal acidity of animals to inhibit pathogenic microbial growth. 
Currently commercialized GODs are mainly from Penicillium spp. and Aspergillus niger. GODs from Penicillium spp. possess much higher catalytic efficiency than that of GOD from A. niger. The substrate affinity of Penicillium amagasakiense GOD is six times higher than that of $A$. niger and the catalytic efficiency $\left(k_{\text {cat }} / K_{\mathrm{m}}\right)$ is even more than 10 times higher. However, Penicillium GODs exhibited poorer thermostability than that of GOD from A. niger. The activity of GOD derived from P. amagasakiense decreased rapidly when the temperature exceeded $60^{\circ} \mathrm{C}[7,8]$. The poor thermostability of Penicillium GOD has become a key limiting factor preventing its widespread application. Therefore, it is of great practical significance to improve the thermal stability of GOD, especially the GOD from Penicillium spp.

The specific structures of proteins are closely related to their thermal stability. Many factors affect the specific structure of proteins, such as amino acid composition characteristics, hydrogen bonds, hydrophobic interactions, electrostatic forces, salt bridges and the stability of loops [9-12]. Protein structure is the combined effect of these factors in an enzyme molecule, and any changes to these forces may lead to changes in stability. In particular, protein free unfolding energy $(\Delta G)$ is one of the most important parameters for the thermodynamic stability of proteins and a main indicator of protein thermostability. The effect of mutations on the thermostability of a protein can be determined by calculating the change in the $\Delta \mathrm{G}$ value $(\Delta \Delta \mathrm{G})$ after protein mutation, which can be predicted with computer simulations. Molecular dynamics (MD) simulations have been used to identify valuable residues that could lead to significant differences in $\Delta \mathrm{G}$. For example, the thermostability of methyl parathion hydrolase from Ochrobactrum and lipase B from Candida antarctica have been improved substantially using this strategy [13,14], increasing the temperature at which half the protein molecules denature $\left(T_{\mathrm{m}}\right)$ of the mutant enzyme by $11.7^{\circ} \mathrm{C}$ [13] and $3.6^{\circ} \mathrm{C}$ [14] compared to the wild-type, respectively.

In addition to the aforementioned factors, there is a special factor that affects the stability of GOD. GOD is a glycoprotein with a molecular mass of 150-170 kDa from fungi [15-17]. It is a homodimer of $\sim 80 \mathrm{kDa}$ monomers, each of which contains two structural domains, one containing the substrate binding site, and the other housing tightly, but non-covalently, bound flavin adenine dinucleotide (FAD) as a coenzyme. Previous results have suggested that the dissociation of FAD resulted in the destabilized tertiary structures of GOD and it has a critical role in the structure and activity of GOD $[18,19]$. Therefore, the binding strength of FAD with its surrounding amino acids may also affect the thermostability of GOD.

A god gene (GenBank accession number: JN809249) was cloned from Penicillium notatum F4 in our previous work, and a codon-optimised godm gene has been successfully overexpressed in Pichia pastoris [20] and obtained the protein $\mathrm{GOD}_{\mathrm{m}}$. In the present study, we performed computer-aided design with key amino acid site-directed saturation mutagenesis to improve the thermostability of $\mathrm{GOD}_{\mathrm{m}}$. The key factors affecting the thermostability of $\mathrm{GOD}_{\mathrm{m}}$ were analysed at the protein structure level, and two mutants with significantly improved thermostabilities, S100A and D408W, were obtained.

\section{Results}

\subsection{Selection of Mutant Sites}

$\Delta \mathrm{G}$ is an integrated parameter for the thermodynamic stability of proteins, and the $\Delta \Delta \mathrm{G}$ after protein mutation can be predicted with computer simulations. Here, the effects of single point mutations on the $\Delta \Delta \mathrm{G}$ of $\mathrm{GOD}_{\mathrm{m}}$ were evaluated with the Prethermut program [13]. It was considered to exhibit potentially positive effects on protein thermostability when $\Delta \Delta G$ was greater than 0.5 and potentially negative effects when it was below 0.5 [13]. The results showed that the amino acids Asp82 (D82), Asp408 (D408) and Glu476 (E476) could be key sites related to protein thermostability (Figure $1 b)$. The $\Delta G$ of most mutants decreased significantly $(\Delta \Delta G>0.5)$ when these amino acids were mutated into other amino acids, indicative of potentially beneficial mutant positions. 


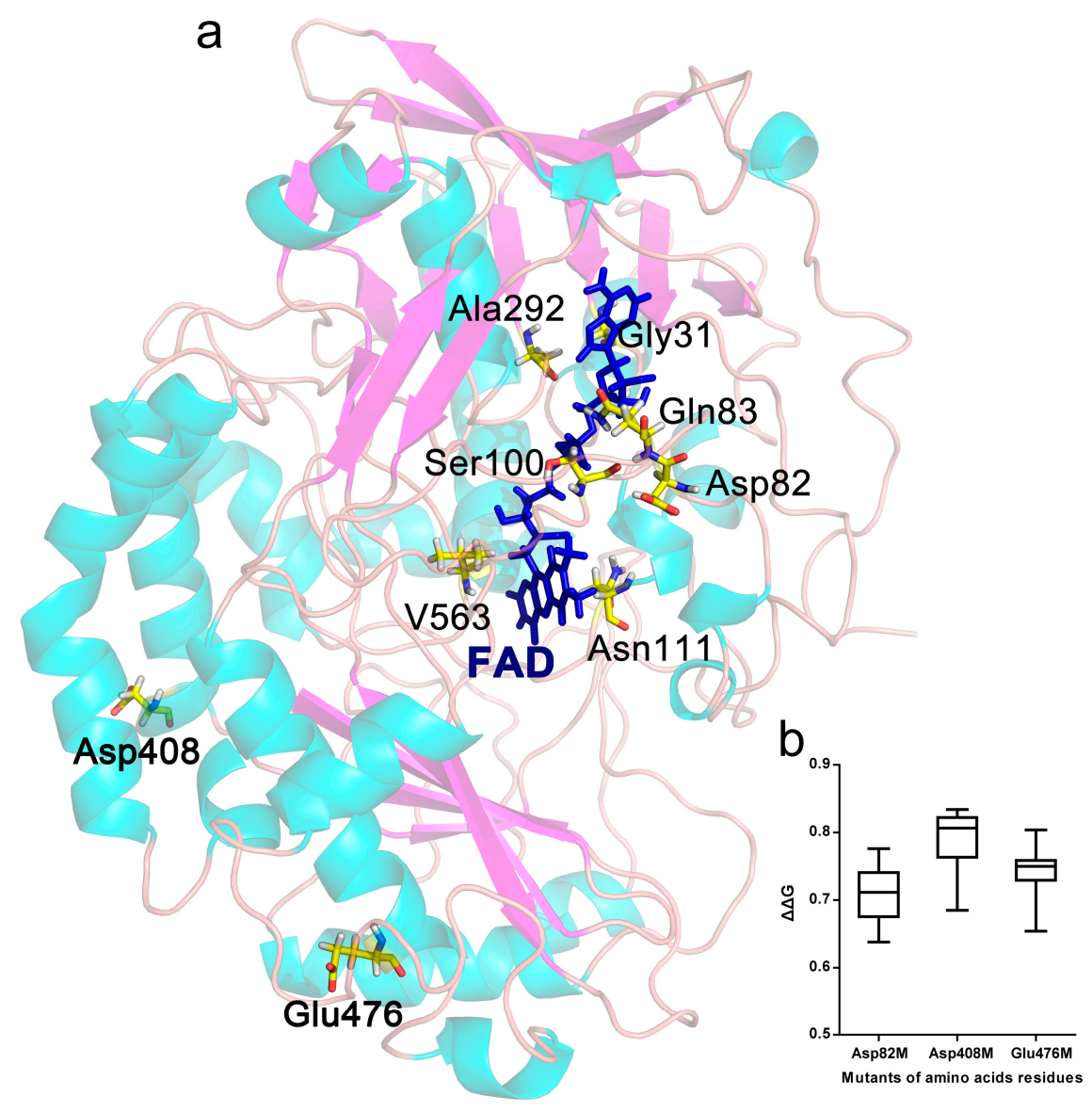

Figure 1. $\mathrm{GOD}_{\mathrm{m}}$ sites chosen for saturation mutagenesis. (a) Ribbon plot of the three-dimensional structure of $\mathrm{GOD}_{\mathrm{m}}$ from P. notatum F4. The selected residues were Asp82, Asp408, Glu476, Gly31, Gln83, Ser100, Asn111, Ala292 and Val563, as shown using the yellow stick model. The blue stick model represented flavin adenine dinucleotide (FAD). The Gly31, Gln83, Ser100, Asn111, Ala292 and Val563 distributed within $5 \AA$ around the coenzyme FAD. The secondary structures of $G \mathrm{DD}_{\mathrm{m}}$ are colored aqua for helixes and purple for sheets. (b). Potential mutant sites whose average of the change in the protein free unfording energy $(\Delta \Delta \mathrm{G})$ values were greater than 0.5 .

The distribution of all amino acids within $5 \AA$ around the coenzyme FAD in the GOD $\mathrm{m}_{\mathrm{m}}$ structure was analysed with Discovery Studio 2.5 software (Accelrys, San Diego, CA, USA), and the non-covalent interactions between FAD and the surrounding amino acids were analysed. The results showed that mutation of the amino acids Gly31 (G31), Gln83 (Q83), Ser100 (S100), Asn111 (N111), Ala292 (A292) and Val563 (V563) of $\mathrm{GOD}_{\mathrm{m}}$ potentially enhanced the binding strength between FAD and $\mathrm{GOD}_{\mathrm{m}}$ due to increased hydrogen and $\pi$ bonds (Figure 1a and S1).

\subsection{Mutant Library Construction}

Single point mutant libraries corresponding to the nine preselected sites were constructed based on site-directed saturation mutagenesis method. The mutation site was designed with NNK degeneracy $(\mathrm{N}$, adenine/cytosine/guanine/thymine; $\mathrm{K}$, guanine/thymine) to encode all 20 amino acids. The site-directed saturation mutagenesis and homologous recombination in vitro were based on polymerase chain reaction (PCR) and CloneEZ Enzyme. At least 20 colonies from each E. coli-mutated library were randomly selected and sequenced with specific primers to detect nucleotide sequences. The mutant rates of the E. coli-mutated libraries were above $90 \%$. The resultant recombinant expression vectors were extracted from E. coli and transferred into P. pastoris. After screening based on chromogenic reaction, each mutant library included at least 200 positive transformants. 


\subsection{Thermostable Mutant Selection}

The positive transformants were induced, and culture supernatants were collected as crude enzyme solutions since the recombinant $\mathrm{GOD}_{\mathrm{m}} \mathrm{s}$ was secretory. The enzyme activity was measured after treatment at $55^{\circ} \mathrm{C}$ for $10 \mathrm{~min}$. The transformants with higher residual activities (1.2 times higher than that of the wild-type) were selected as potential candidates. The changed amino acids in the potential candidates were detected through DNA sequencing. Finally, seven mutants (D408W, D408T, D408K, D408C, E476T, E476K and S100A) were obtained from the nine mutant libraries. The crude enzymes of these mutants were purified by anion exchange chromatography. The results of sodium dodecyl sulfate polyacrylamide gel electrophoresis (SDS-PAGE) analysis showed that all of the mutants reached electrophoretic purity (Figure S2). The predicted molecular weights based on SDS-PAGE were around $80 \mathrm{kDa}$, near the theoretical molecular weight of $\mathrm{GOD}_{\mathrm{m}}$.

\subsection{Thermostability and Optimum Temperature of the Mutants}

The protein concentrations of the pure enzyme solutions were standardised to $10 \mu \mathrm{g} / \mathrm{mL}$, and then treated at $55{ }^{\circ} \mathrm{C}$ for $0,10,30,60,120$ and $180 \mathrm{~min}$. The enzyme activity at $55{ }^{\circ} \mathrm{C}$ for 0 min was considered as $100 \%$, the specific activities of the wild-type protein, D408W, D408T, D408K, D408C, E476T, E476K and S100A were 55.7, 75.4, 73.2, 66.3, 70.5, 84.3, 52.3 and 85.4 U/mg, respectively. Among the seven mutants, most were more stable than the wild-type protein, especially D408W and S100A. The residual activities of the wild-type, D408W, S100A, D408T, D408K and E476K were $20 \%, 74 \%, 72 \%, 68 \%, 62 \%$ and $53 \%$ respectively, after treatment for $180 \mathrm{~min}$ (Figure 2a). The half-life $\left(t_{1 / 2}\right)$ of the wild-type was $75.3 \mathrm{~min}$, while that of D408W was $407.7 \mathrm{~min}, 4.4$-fold higher than that of the wild-type, and that of S100A was $462.1 \mathrm{~min}, 5.1$-fold higher than that of the wild-type (Table 1). The $t_{1 / 2}$ of D408T, D408K and E476K were 315.1, 239.0, $216.6 \mathrm{~min}$, respectively (Table 1). The thermostability of E476T was similar to that of the wild-type. The residual activity of D408C was $10 \%$ lower than the wild-type after treatment at $55{ }^{\circ} \mathrm{C}$ for $180 \mathrm{~min}$ (Figure 2a), and its $t_{1 / 2}$ was 18 min shorter than the wild-type. The thermostability of all the mutants with improved thermostability at $55{ }^{\circ} \mathrm{C}$ were further compared with that of the wild-type at $60^{\circ} \mathrm{C}$. After treatment for $10 \mathrm{~min}$, the retention rates of the wild-type, S100A and D408W were $5.6 \%, 72.8 \%$ and $20.8 \%$, respectively. After treatment at $60{ }^{\circ} \mathrm{C}$ for $30 \mathrm{~min}$, the wild-type was completely inactivated, while S100A and D408W had $40 \%$ and $8.1 \%$ residual activities (Figure $2 \mathrm{~b}$ ). However, the other mutants did not exhibit significantly increased thermostability at $60^{\circ} \mathrm{C}$. Furthermore, the optimum temperature of these mutants was $40{ }^{\circ} \mathrm{C}$, showing no difference to the wild-type enzyme (Figure 2c).
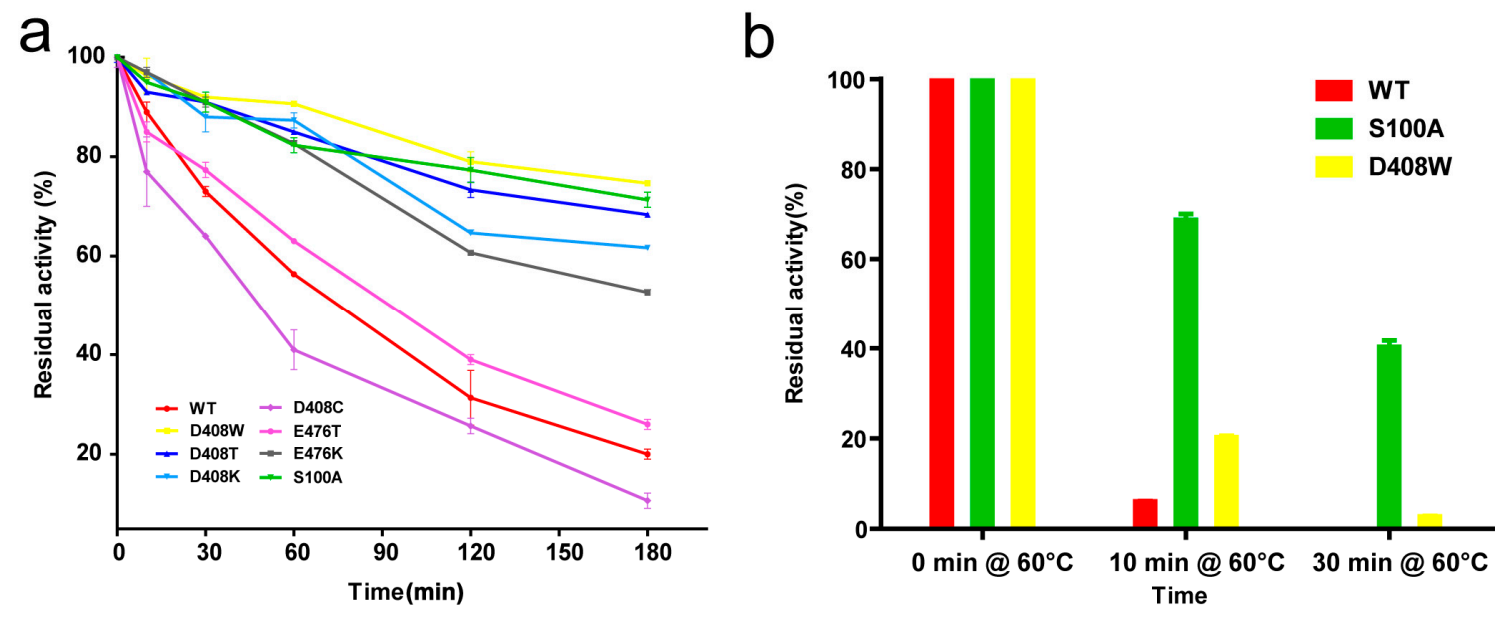

Figure 2. Cont. 

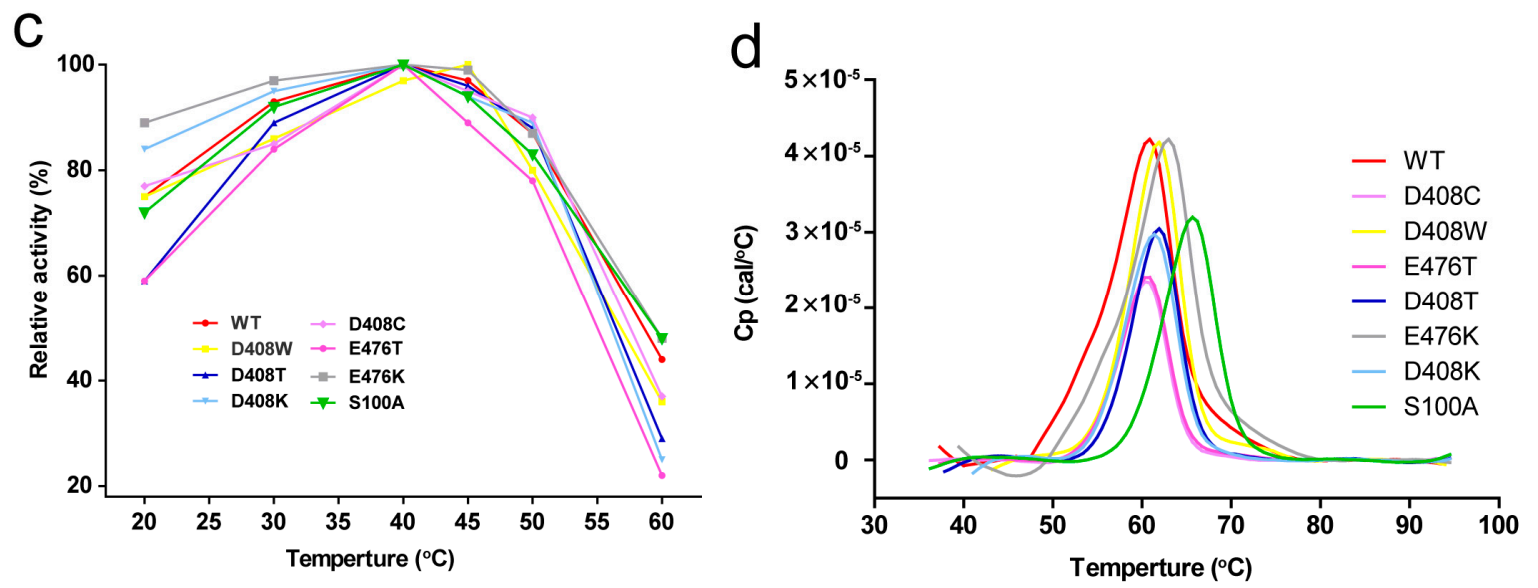

Figure 2. Thermostability of wild-type and mutant $\mathrm{GOD}_{\mathrm{m}}$. (a) Residual activity of the wild-type $\mathrm{GOD}_{\mathrm{m}}$ and mutants after treatment at $55^{\circ} \mathrm{C}$ for different times. Data points correspond to the mean values of three independent experiments. The activity of the untreated enzyme was considered as $100 \%$; (b) Residual activities of the wild-type $\mathrm{GOD}_{\mathrm{m}}, \mathrm{S} 100 \mathrm{~A}$ and $\mathrm{D} 408 \mathrm{~W}$ after incubation at $60{ }^{\circ} \mathrm{C}$; (c) Optimum temperature of the wild-type $\mathrm{GOD}_{\mathrm{m}}$ and mutants. The highest activities of the mutants and wild-type $\mathrm{GOD}_{\mathrm{m}}$ were considered as $100 \%$; (d) Temperature-induced unfolding measured with differential scanning calorimetry for the wild-type and mutant enzymes. The scans were fitted to a curve after subtraction of an instrument-derived baseline recorded with buffer in both holes as calculated using Origin software (Origin Lab, Northampton, MA, USA).

Table 1. Thermostability of the wild-type and mutant enzymes.

\begin{tabular}{ccc}
\hline Mutant & $\boldsymbol{t}_{\mathbf{1 / 2}}(\mathbf{m i n})$ at $\mathbf{5 5}{ }^{\circ} \mathbf{C}$ & $\boldsymbol{T}_{\mathbf{m}}\left({ }^{\circ} \mathbf{C}\right)$ \\
\hline WT & 75.3 & 60.7 \\
D408W & 407.7 & 61.9 \\
D408T & 315.1 & 61.7 \\
D408K & 239.0 & 61.6 \\
D408C & 57.3 & 60.1 \\
E476T & 110.0 & 60.9 \\
E476K & 216.6 & 62.0 \\
S100A & 462.1 & 65.1
\end{tabular}

$t_{1 / 2}=\ln 2 / K_{D}$, where the rate constant $K_{D}$ is the time to reach the abscissa in the plot, $\ln \left(U_{t} / U_{0}\right)$ is the ordinate, $\mathrm{U}_{\mathrm{t}}$ is the time $t$ of enzyme activity, and $\mathrm{U}_{0}$ is the time 0 of enzyme activity.

\subsection{Determination of $T_{m}$}

$T_{\mathrm{m}}$ values were determined with differential scanning calorimetry (DSC; GE Healthcare Life Science; Pittsburgh, PA, USA) from $30{ }^{\circ} \mathrm{C}$ to $95{ }^{\circ} \mathrm{C}$. The concentration of purified protein was standardised to $200 \mu \mathrm{g} / \mathrm{mL}$. The measured data were fitted to obtain a smooth bell-type protein dissolution curve (Figure 2d), where the temperature corresponding to the curve peak represented $T_{\mathrm{m}}$. S100A was the only mutant that showed a significant increase in $T_{\mathrm{m}}$ among the mutants, as the $T_{\mathrm{m}}$ value of S100A increased by $4.4{ }^{\circ} \mathrm{C}$ compared with the wild-type. The $T_{\mathrm{m}}$ values of $\mathrm{D} 408 \mathrm{~K}, \mathrm{D} 408 \mathrm{~W}$, D408T and E476K were $0.9-1.3^{\circ} \mathrm{C}$ higher than that of the wild-type. Meanwhile, the $T_{\mathrm{m}}$ of D408C was $0.6{ }^{\circ} \mathrm{C}$ lower than that of the wild-type and the $T_{\mathrm{m}}$ of E476T was similar to the wild-type, with no significant difference (Table 1 ).

\subsection{Protein Structure Analysis}

We explored the relationship between protein conformation and thermostability based on an MD simulation. The MD simulations of $\mathrm{GOD}_{\mathrm{m}}$ were conducted at $400 \mathrm{~K}$ to assess the stability of the mutants and the wild-type. Figure 3 a shows the root mean square deviation (RMSD) of the backbone 
atoms of the $\mathrm{GOD}_{\mathrm{m}}$ mutants. The RMSD tendencies of most mutants were similar to the wild-type. However, those of S100A were steadier than the wild-type at $400 \mathrm{~K}$ (Figure 3b). The fluctuation of RMSD values was consistent with the fact that the mutants possessed greater thermostability.
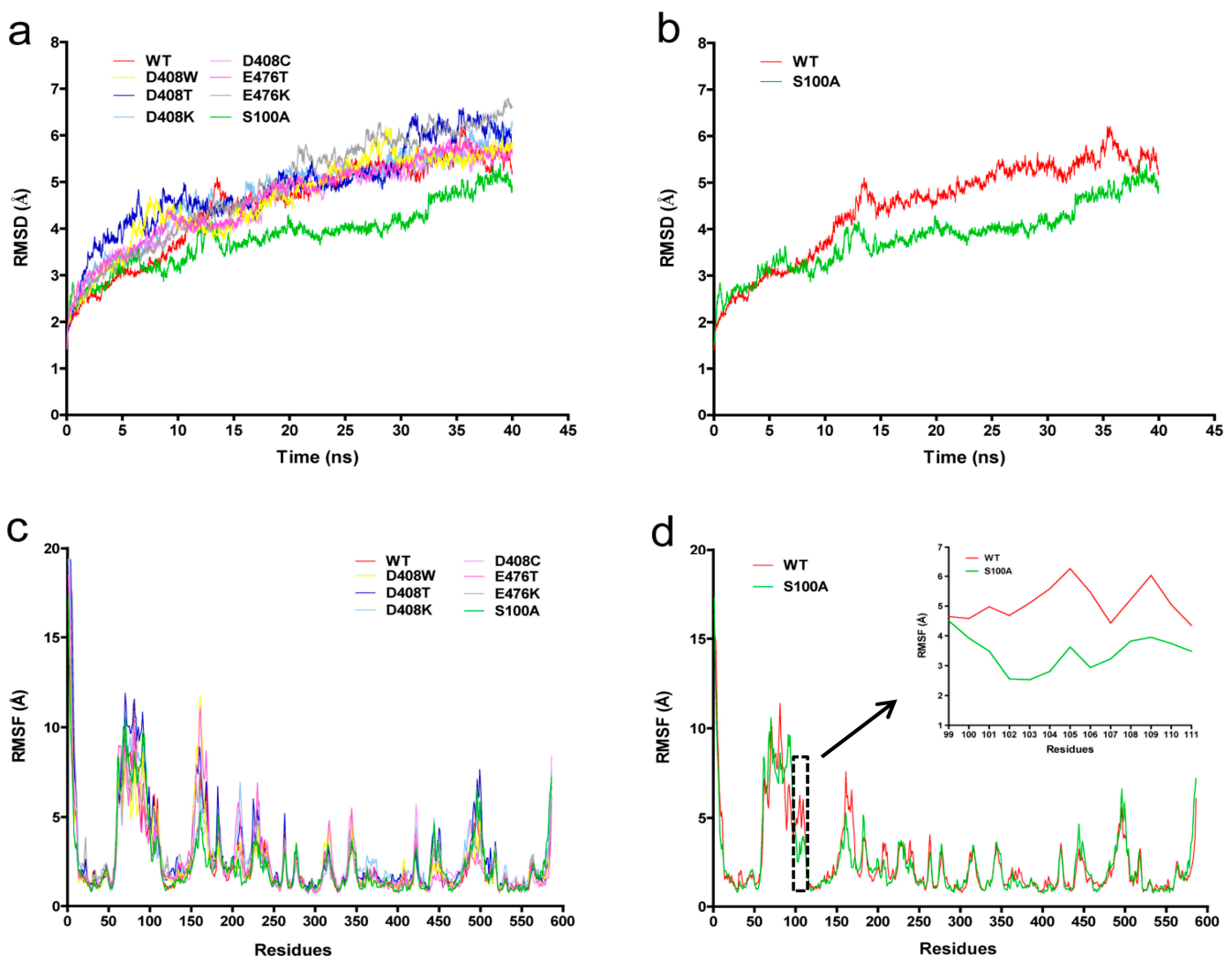

Figure 3. Molecular dynamics (MD) simulation of the protein structure of wild-type and mutant $\mathrm{GOD}_{\mathrm{m}}$. (a) Root mean square deviation (RMSD) values during a 40-ns MD simulation for the wild-type (WT) and mutants at $400 \mathrm{~K}$. The RMSD values of different proteins are shown as different colours; (b) RMSD values of S100A and WT; (c) Root mean square fluctuation (RMSF) values during a 40-ns MD simulation for wild-type and mutants at $400 \mathrm{~K}$. The RMSF values of different proteins are shown as different colours; (d) RMSF values of S100A and WT. RMSF values curve of amino acids located at 99-111 position were boxed in black dotted line and enlarged.

The root mean square fluctuation (RMSF) values reflected the fluctuation of the individual residues during the MD simulation process. The wild-type enzyme had one major unstable region around 51-167 amino acids (Figure 3c). S100 is located in this unstable zone. When serine at position 100 was mutated to alanine, the RMSF value decreased (Figure 3d), a lower RMSF value indicates more stability.

\section{Discussion}

Glucose oxidase is used not only in the food industry and in medical examinations [1], but also as an additive used for monogastric animal feed [2]. However, the poor thermostability of GOD limits its application, especially in the feed industry [21]. Improving the thermostability of GOD can help reduce the loss of activity during the feed pelleting process.

Several approaches have been used to improve the thermostability of GOD in previous studies, including enzyme engineering means such as protein immobilization [22] and protein engineering methods such as directed evolution and rational design. Researchers have improved the thermostability of GOD significantly by directed evolution experiments [23,24]. It is well known that directed evolution is time-consuming and laborious. Alternatively, available protein structure information of GOD makes 
it possible to obtain thermostable mutants through rational design. Marín-Navarro et al. obtained GOD variants with improved thermostability based on rational design aimed at introducing stabilizing salt bridges [12]. In the present study, amino acids putatively related to the thermostability of the enzyme were predicted through a rational computer-aided molecular design strategy based on $\Delta \Delta \mathrm{G}$ and the analysis of amino acids related to the coenzyme FAD, and two mutants with significantly improved thermostability, S100A and D408W, were obtained through site-directed saturation mutagenesis. Our results strongly suggested that rational computer-aided molecular design could be an effective strategy to improve protein thermostability.

We also attempted to investigate the molecular mechanism related to the structural changes and the increased thermal resistance of the mutants. The structural changes in D408W were analyzed with Discovery Studio 2.5, and the results showed that 14 hydrogen bonds could be formed between W408 and other amino acids with distances of $5 \AA$, which was six more than the number of hydrogen bonds D408 formed in the wild-type protein. These bonds may help maintain the hydrogen bond network around W408 and thereby contribute to the improved thermostability. The RMSD tendency of S100A was steadier and the RMSF values of S100A were markedly lower than those of the wild-type enzyme, demonstrating the enhanced rigidity of S100A. Since the S100A resides in the coenzyme domain, this mutation may contribute to the combination of FAD and GOD $\mathrm{m}_{\mathrm{m}}$, thus improving the stability of the $\mathrm{GOD}_{\mathrm{m}}$ tertiary structure. Besides, we speculated that when the hydrophilic amino acid S100 was mutated to hydrophobic A100, which is located inside the tertiary protein structure, it helped to increase the stability of the protein.

This work provides novel and efficient approaches for enhancing the stability of $\mathrm{GOD}_{\mathrm{m}}$ by reducing the $\Delta G$ or increasing the interaction between the amino acids with the coenzyme. With markedly improved thermostability, $\mathrm{GOD}_{\mathrm{m}}$ is better suited for industrial application. In this study, we constructed mutant libraries based on only one mutant site to test the effectiveness of the computer-aided molecular design strategy. To obtain even greater thermostability of this enzyme, we will attempt to construct and screen $\mathrm{GOD}_{\mathrm{m}}$ mutants with combinations of two mutation points in future research.

\section{Materials and Methods}

\subsection{Strains, Plasmids, and Media}

Escherichia coli Trans1-T1 (TransGen, Beijing, China) was used for the gene cloning. Pichia pastoris GS115 (Invitrogen, Carlsbad, CA, USA) was used as the host for recombinant GOD $_{m}$ expression. The P. pastoris-E. coli shuttle expression vector pPIC9-godm was previously constructed by our laboratory [20]. Luria-Bertani (LB) medium, regeneration dextrose base (RDB) medium, minimal methanol (MM) medium, and yeast peptone dextrose (YPD) medium were prepared according to the instructions of the Pichia expression kit (Invitrogen, Carlsbad, CA, USA). Fermentation basal salts (FBS) and PTM trace salts were prepared in compliance with the Pichia fermentation process guidelines (Invitrogen, Carlsbad, CA, USA).

\subsection{Mutant Site Selection}

The protein structure model of $\mathrm{GOD}_{\mathrm{m}}$ was constructed with SWISS-MODEL (https:/ /www. swissmodel.expasy.org/) using Penicillium amagasakiense GOD (PDB accession 1GPE) [25] as a template. An MD simulation was performed on the 1GPE model as the starting structure to select residues with high RMSF values for mutation to improve protein thermostability [26]. Dynamics and trajectory analyses were performed with the software NAnoscale Molecular Dynamics (NAMD) using the charmm 22 force field. An appropriate amount of $\mathrm{NaCl}$ was added to neutralise the system. The LINCS algorithm was used to constrain bond lengths and a 2-fs time step was used. For the simulations at $400 \mathrm{~K}$, production runs were performed for $20 \mathrm{~ns}$ with a 2 -fs step. Temperature and pressure coupling were obtained with v-rescale $[27,28]$. 
The $\Delta \Delta \mathrm{G}$ of $\mathrm{GOD}_{\mathrm{m}}$ was calculated using the software Prethermut. All possible single-point saturation mutants of $\mathrm{GOD}_{\mathrm{m}}$ with $\Delta \Delta \mathrm{G}$ values above 0.5 compared with the wild-type were selected [29]. The amino acid residues were selected based on the RMSF and $\Delta \Delta G$ values. Discovery studio 2.5 software was used to determine the distribution of all amino acids within $5 \AA$ of the coenzyme FAD in the $\mathrm{GOD}_{\mathrm{m}}$ structure. The surrounding amino acids that could affect the binding intensity were analysed.

\subsection{Plasmid Construction}

The mutant plasmids were constructed based on a DNA assembly cloning kit $\left(\right.$ CloneEZ $^{\circledR}$ PCR Cloning Kit, Genscript, Nanjing, China), which could assemble DNA fragments with varied overlaps (15-80 bp) (construction steps are shown in Figure S3). The strategy involved two pairs of partially overlapping primers (Bgl II-F and Bgl II-R, special F and special R), with 20-25-nt overlapping regions at the $5^{\prime}$-ends of the primers. Primer was designed with a mutant base NNK $(\mathrm{N}$, adenine/cytosine/guanine/thymine; K, guanine/thymine) which was located in the middle of the special F [13] (Table S1). Fragment 1 (using Bgl II-F and special R primer) and fragment 2 (using special $\mathrm{F}$ and Bgl II-R primer) were amplified from the pPIC9-GOD $m$ plasmid with FastPfu DNA Polymerase (TransGen, Beijing, China) with PCR. The PCR parameters were as follows: denaturation at $94{ }^{\circ} \mathrm{C}$ for $5 \mathrm{~min}, 30$ cycles of $30 \mathrm{~s}$ at $94{ }^{\circ} \mathrm{C}, 30 \mathrm{~s}$ at $58^{\circ} \mathrm{C}$, and $1 \mathrm{~min}$ at $72{ }^{\circ} \mathrm{C}$, followed by $10 \mathrm{~min}$ at $72{ }^{\circ} \mathrm{C}$. Two DNA fragments were homologous to each other, one of which had a mutant base. The fragments were purified using a PCR purification kit and then combined using CloneEZ ${ }^{\circledR}$ PCR Cloning Kit.

The recombinant plasmids were transformed into E. coli Trans1-T1. The colonies grew on LB solid medium containing ampicillin, and single colonies were randomly selected from the LB solid medium and DNA from the colonies was sequenced with specific primers to confirm the nucleotide sequences of the mutated sites. The sequencing results were analysed to ensure that the mutant rate was higher than $90 \%$. All transformants were scraped and inoculated into LB liquid medium. Mixed plasmids were extracted after culturing at $37^{\circ} \mathrm{C}$ for $12 \mathrm{~h}$.

\subsection{Positive Transformant Screening}

The mixed plasmids were linearised with BglII, and then transformed into P. pastoris GS115 competent cells by electroporation. Transformants were cultivated on RDB plates at $28^{\circ} \mathrm{C}$ for $48 \mathrm{~h}$, and then inoculated and incubated on MM plates for another $24 \mathrm{~h}$. The positive transformants were screened by chromogenic reaction for $30 \mathrm{~min}$ at room temperature [30]. Individual positive transformants were placed in 48-well microtiter plates containing $500 \mu \mathrm{L}$ of buffered glycerol complex (BMGY) medium, and then incubated at $28^{\circ} \mathrm{C}$ for $48 \mathrm{~h}$ with $200 \mathrm{r} / \mathrm{min}$ of shaking. The transformants were cultivated further in buffered methanol complex medium (BMMY) at $28{ }^{\circ} \mathrm{C}$ for $48 \mathrm{~h}$ after the BMGY medium was discarded by centrifugation. The enzyme solutions were harvested by centrifugation and then transferred into 96-well plates. The enzyme solutions were heated to $55^{\circ} \mathrm{C}$ for $10 \mathrm{~min}$ and then immediately placed on ice. The treated samples were used for the enzyme activity assay. Transformants with high residual activity were selected as potentially positive mutants. The mutant gene sequences of the transformants were amplified by PCR and sequenced.

\subsection{Protein Expression and Purification}

The cells were cultured in $200 \mathrm{~mL}$ of YPD medium in a 500-mL shake flask for $48 \mathrm{~h}$. The cells were harvested by centrifugation, and then resuspended in $200 \mathrm{~mL}$ of FBS (where glucose acted as the sole carbon source) for $24 \mathrm{~h}$. Finally, the cells were harvested by centrifugation and resuspended in $100 \mathrm{~mL}$ of FBS with $1 \%$ methanol for $72 \mathrm{~h}$. The culture supernatant was harvested by centrifugation at $8000 \mathrm{~g} / \mathrm{min}$ for $10 \mathrm{~min}$. The above crude enzyme solution was desalted and purified according to the methods described previously [31]. The protein purity was evaluated with SDS-PAGE. 


\subsection{Enzyme Assay}

Glucose oxidase activity was measured following the method described previously [20].

\subsection{Thermostability Assay}

Enzyme thermostability was characterised with o-dianisidine, D-glucose, and horseradish peroxidase as the substrates. The enzyme solution was treated at $55^{\circ} \mathrm{C}$ for $0,10,30,60,120$ and $180 \mathrm{~min}$ and the activity was measured under standard conditions. The activity of the untreated enzyme was considered as $100 \%$, and mutants with high residual activities were selected for subsequent analysis. The optimal temperature for $\mathrm{GOD}_{\mathrm{m}}$ activity was determined based on the standard enzyme assays in the range of $20-60{ }^{\circ} \mathrm{C}$ in $100 \mathrm{mM} \mathrm{NaH}_{2} \mathrm{PO}_{4} / \mathrm{Na}_{2} \mathrm{HPO}_{4}$ buffer (pH 6.2).

The half-lives of the wild-type and mutant enzymes were determined by incubation in water baths at $55{ }^{\circ} \mathrm{C}$. Samples were incubated for various times, and then placed immediately on ice. The residual activities of the samples were measured using a standard assay, where $t_{1 / 2}=\ln 2 / \mathrm{K}_{\mathrm{D}}$. The rate constant, $\mathrm{K}_{\mathrm{D}}$, was calculated using GraphPad Prism software (GraphPad Software, Inc., La Jolla, CA, USA).

The $T_{\mathrm{m}}$ was measured to indicate the stability of protein unfolding. The protein concentration was standardised to $200 \mu \mathrm{g} / \mathrm{mL}$. DSC was used to measure $T_{\mathrm{m}}$. The samples were diluted in $0.02 \mathrm{M}$ sodium phosphate buffer ( $\mathrm{pH}$ 6.0) and heated from $30{ }^{\circ} \mathrm{C}$ to $95{ }^{\circ} \mathrm{C}$. Each sample was tested three times in 96-well plates.

\subsection{Mutant Protein Structure Analysis}

The mutant $\mathrm{GOD}_{\mathrm{m}}$ was evaluated with an MD simulation with PyMOL (Delano Scientific, San Carlos, CA, USA) and Discovery Studio 2.5 software. The RMSD and RMSF values were measured. The key amino acids affecting the thermostability of $\mathrm{GOD}_{\mathrm{m}}$ were revealed through the protein structures analysis.

Supplementary Materials: Supplementary materials can be found at http:/ /www.mdpi.com/1422-0067/19/2/ $425 /$ s1.

Acknowledgments: This research was supported by the National Natural Science Foundation of China (grant number 31201313) and the National High Technology Research and Development Program of China (863 Program, grant number 2012AA022207).

Author Contributions: Yuhong Zhang, Xinxin $\mathrm{Xu}$, Xiaoyan Ning and Yanli Zhang conceived and designed the experiments; Xiaoyan Ning, Yanli Zhang, Tiantian Yuan and Weishi Guan performed the experiments; Xiaoyan Ning, Yanli Zhang, Qingbin Li, Jian Tian and Bo Liu analyzed the data; Wei Zhang contributed reagents/materials/analysis tools; Xiaoyan Ning, Yuhong Zhang and Xinxin Xu wrote the paper.

Conflicts of Interest: The authors declare no conflict of interest.

\section{References}

1. Bankar, S.B.; Bule, M.V.; Singhal, R.S.; Ananthanarayan, L. Glucose oxidase-An overview. Biotechnol. Adv. 2009, 27, 489-501. [CrossRef] [PubMed]

2. Huo, F.; Wang, Y.; Fu, S. Application progresses of glucose oxidase (GOD) in feed. Anim. Husb. Feed Sci. 2015, 7, 298-300.

3. Hatzinikolaou, D.G.; Macris, B.J. Factors regulating production of glucose oxidase by Aspergillus niger. Enzyme Microb. Tech. 1995, 17, 530-534. [CrossRef]

4. Petruccioli, M.; Federici, F.; Bucke, C.; Keshavarz, T. Enhancement of glucose oxidase production by Penicillium variabile p16. Enzyme Microb. Technol. 1999, 24, 397-401. [CrossRef]

5. Bonet, A.; Rosell, C.M.; Caballero, P.A.; Gómez, M.; Pérez-Munuera, I.; Lluch, M.A. Glucose oxidase effect on dough rheology and bread quality: A study from macroscopic to molecular level. Food Chem. 2006, 99, 408-415. [CrossRef]

6. Savas Anastassiadis, I.G.M. Gluconic acid production. Recent Pat. Biotechnol. 2007, 1, 167-180. [CrossRef] 
7. Kalisz, H.M.; Hendle, J.; Schmid, R.D. Structural and biochemical properties of glycosylated and deglycosylated glucose oxidase from Penicillium amagasakiense. Appl. Microbiol. Biotechnol. 1997, 47, 502-507. [CrossRef] [PubMed]

8. Holland, J.T.; Harper, J.C.; Dolan, P.L.; Manginell, M.M.; Arango, D.C.; Rawlings, J.A.; Apblett, C.A.; Brozik, S.M. Rational redesign of glucose oxidase for improved catalytic function and stability. PLoS ONE 2012, 7, e37924. [CrossRef] [PubMed]

9. Khan, S.; Vihinen, M. Performance of protein stability predictors. Hum. Mutat. 2010, 31, 675-684. [CrossRef] [PubMed]

10. Benedix, A.; Becker, C.M.; de Groot, B.L.; Caflisch, A.; BöCkmann, R.A. Predicting free energy changes using structural ensembles. Nat. Methods 2009, 6, 3-4. [CrossRef] [PubMed]

11. Razvi, A.; Scholtz, J.M. Lessons in stability from thermophilic proteins. Protein Sci. 2006, 15, 1569-1578. [CrossRef] [PubMed]

12. Marín-Navarro, J.; Roupain, N.; Talens-Perales, D.; Polaina, J. Identification and structural analysis of amino acid substitutions that increase the stability and activity of Aspergillus niger glucose oxidase. PLOS ONE 2015, 10, e0144289. [CrossRef] [PubMed]

13. Tian, J.; Wang, P.; Huang, L.; Chu, X.; Wu, N.; Fan, Y. Improving the thermostability of methyl parathion hydrolase from Ochrobactrum sp. M231 using a computationally aided method. Appl. Microbiol. Biotechnol. 2013, 97, 2997-3006. [CrossRef] [PubMed]

14. Xie, Y.; An, J.; Yang, G.; Wu, G.; Zhang, Y.; Cui, L.; Feng, Y. Enhanced enzyme kinetic stability by increasing rigidity within the active site. J. Biol. Chem. 2014, 289, 7994-8006. [CrossRef] [PubMed]

15. Hatzinikolaou, D.G.; Hansen, O.C.; Macris, B.J.; Tingey, A.; Kekos, D.; Goodenough, P.; Stougaard, P. A new glucose oxidase from Aspergillus niger: Characterization and regulation studies of enzyme and gene. Appl. Microbiol. Biotechnol. 1996, 46, 371-381. [PubMed]

16. Kiess, M.; Hecht, H.J.; Kalisz, H.M. Glucose oxidase from Penicillium amagasakiense. Eur. J. Biochem. 1998, 252, 90. [CrossRef] [PubMed]

17. O'Malley, J.J.; Weaver, J.L. Subunit structure of glucose oxidase from Aspergillus niger. Biochemistry 1972, 11, 3527-3532. [CrossRef] [PubMed]

18. Caves, M.S.; Derham, B.K.; Jezek, J.; Freedman, R.B. The mechanism of inactivation of glucose oxidase from Penicillium amagasakiense under ambient storage conditions. Enzyme Microb. Technol. 2011, 49, $79-87$. [CrossRef] [PubMed]

19. Garajová, K.; Zimmermann, M.; Petrenčáková, M.; Dzurová, L.; Nemergut, M.; Škultéty, L'; Žoldák, G.; Sedlák, E. The molten-globule residual structure is critical for reflavination of glucose oxidase. Biophys. Chem. 2017, 230, 74-83. [CrossRef] [PubMed]

20. Gao, Z.; Li, Z.; Zhang, Y.; Huang, H.; Li, M.; Zhou, L.; Tang, Y.; Yao, B.; Zhang, W. High-level expression of the Penicillium notatum glucose oxidase gene in Pichia pastoris using codon optimization. Biotechnol. Lett. 2012, 34, 507-514. [CrossRef] [PubMed]

21. Thaqi, M.; Zenelaj, I.; Jaka, F. Testing of pelleting efficiency, quality and effect of pelleted feed on broiler performance. In Proceedings of the 36th International Symposium 'Actual tasks on agricultural engineering', Opatija, Croatia, 10-13 February 2009; pp. 527-537.

22. He, C.; Liu, J.; Xie, L.; Zhang, Q.; Li, C.; Gui, D.; Zhang, G.; Wu, C. Activity and thermal stability improvements of glucose oxidase upon adsorption on core-shell pmma-bsa nanoparticles. Langmuir 2009, 25, 13456-13460. [CrossRef] [PubMed]

23. Zhu, Z.; Wang, M.; Gautam, A.; Nazor, J.; Momeu, C.; Prodanovic, R.; Schwaneberg, U. Directed evolution of glucose oxidase from Aspergillus niger for ferrocenemethanol-mediated electron transfer. Biotechnol. J. 2007, 2, 241-248. [CrossRef] [PubMed]

24. Ostafe, R.; Prodanovic, R.; Nazor, J.; Fischer, R. Ultra-high-throughput screening method for the directed evolution of glucose oxidase. Chem. Biol. 2014, 21, 414-421. [CrossRef] [PubMed]

25. Wohlfahrt, G.; Witt, S.; Hendle, J.; Schomburg, D.; Kalisz, H.M.; Hecht, H.J. 1.8 and 1.9 angstrom resolution structures of the Penicillium amagasakiense and Aspergillus niger glucose oxidases as a basis for modelling substrate complexes. Acta Crystallogr. D 1999, 55, 969-977. [CrossRef] [PubMed]

26. Tian, J.A.; Wang, P.; Gao, S.; Chu, X.Y.; Wu, N.F.; Fan, Y.L. Enhanced thermostability of methyl parathion hydrolase from Ochrobactrum sp. M231 by rational engineering of a glycine to proline mutation. FEBS J. 2010, 277, 4901-4908. [CrossRef] [PubMed] 
27. Soler, M.A.; de Marco, A.; Fortuna, S. Molecular dynamics simulations and docking enable to explore the biophysical factors controlling the yields of engineered nanobodies. Sci. Rep. 2016, 6, 1-11. [CrossRef] [PubMed]

28. Leone, S.; Picone, D. Molecular dynamics driven design of $\mathrm{pH}$-stabilized mutants of MNEI, a sweet protein. PLoS ONE 2016, 11, e0158372. [CrossRef] [PubMed]

29. Tian, J.; Wu, N.; Chu, X.; Fan, Y. Predicting changes in protein thermostability brought about by single- or multi-site mutations. BMC Bioinform. 2010, 11, 370. [CrossRef] [PubMed]

30. Valdivieso-Ugarte, M.; Ronchel, C.; Banuelos, O.; Velasco, J.; Adrio, J.L. Expression of an Aspergillus niger glucose oxidase in Saccharomyces cerevisiae and its use to optimize fructo-oligosaccharides synthesis. Biotechnol. Prog. 2006, 22, 1096-1101. [CrossRef] [PubMed]

31. Nie, C.; Liu, B.; Zhang, Y.; Zhao, G.; Fan, X.; Ning, X.; Zhang, W. Production and secretion of Lactobacillus crispatus beta-galactosidase in Pichia pastoris. Protein Expr. Purif. 2013, 92, 88-93. [CrossRef] [PubMed]

(C) 2018 by the authors. Licensee MDPI, Basel, Switzerland. This article is an open access article distributed under the terms and conditions of the Creative Commons Attribution (CC BY) license (http://creativecommons.org/licenses/by/4.0/). 